\title{
THE EFFECT OF THINK-PAIR-SHARE TECHNIQUE ON THE STUDENTS' ACHIEVEMENT IN READING COMPREHENSION AT THE SECOND SEMESTER STUDENTS OF FKIP NOMMENSEN UNIVERSITY PEMATANGSIANTAR
}

\author{
Partohap S.R Sihombing \\ Sihombingp11@yahoo.co.id \\ Universitas HKBP Nommensen
}

\begin{abstract}
ABSTRAK
Tujuan dari penelitian ini adalah untuk mengetahui pengaruh teknik ThinkPair-Share terhadap pencapaian siswa dalam pemahaman membaca pada mahasiswa semester dua Universitas FKIP Nommensen Pematangsiantar. Penulis menggunakan desain penelitian kuantitatif dan populasi penelitian ini adalah dari mahasiswa semester dua Universitas FKIP Nommensen Pematangsiantar yang terdiri dari 270 siswa. Penulis mengambil 2 kelas atau 60 siswa adalah sampel 30 siswa dari kelompok eksperimen (C) dan 30 siswa dari kelompok kontrol (D). Temuan penelitian menunjukkan bahwa rata-rata kelompok eksperimen lebih tinggi daripada kelompok kontrol rata-rata $(65,06>29,93)$. Hasil pengujian hipotesis menunjukkan bahwa T_OBS lebih tinggi dari T_table $(66,15>$ 2,00). Itu berarti bahwa $H \_a$ diterima dan H_o ditolak. Akhirnya, disimpulkan bahwa ada pengaruh yang signifikan menggunakan teknik Think-Pair-Share pada pencapaian siswa dalam pemahaman membaca pada mahasiswa semester dua FKIP Nommensen Universitas Pematangsiantar. Disarankan agar para guru menerapkan teknik ThinkPair-Share dalam pengajaran membaca pada mahasiswa semester dua FKIP Universitas Nommensen Pematangsiantar.
\end{abstract}

Kata kunci: Think Pair Share Technique, Prestasi, Pemahaman Bacaan

\begin{abstract}
The aim of the research is to find out the effect of Think-Pair-Share technique on the students' achievement in reading comprehension at the second semester students of FKIP Nommensen University Pematangsiantar. The writer uses quantitative research design and the population of this study is from the second semester students of FKIP
\end{abstract}


Nommensen University Pematangsiantar that consists of 270 students. The writer takes 2 classes or 60 students are the sample 30 students from experimental group (C) and 30 students from control group (D). The research findings show that the mean of experimental group is higher than the mean of control group $(65,06>29,93)$. The result of the hypothesis testing showed that $T_{O B S}$ is higher than $T_{\text {table }}(66,15>2,00)$. It means that $H_{a}$ is accepted and $H_{o}$ is rejected. Finally, it is concluded that there is a significant the effect of using Think-Pair-Share technique on the students' achievement in reading comprehension at the second semester students of FKIP Nommensen University Pematangsiantar. It is suggested that the teachers apply Think-Pair-Share technique in teaching reading comprehension at the second semester students of FKIP Nommensen University Pematangsiantar.

Key words : Think Pair Share Technique, Achievement, Reading Comprehension

\section{INTRODUCTION}

In the globalization era, English plays an important role especially in international communication and in the development of education, politic, economy, and tourism. Many people use it as a means of the international communication, it is considered as one of the international languages that are most widely used all over the world. There are four skills that have to be developed in learning language, namely reading, writing, speaking, and listening.

Reading is essential skill for all students at all levels.
Knowledge is derived from reading because reading refers to the ability to comprehend written text (Brasel 2008, p. 15). When a student understands what she reads, she has already acquired some knowledge. The knowledge is later expanded by reading another text. Students can read whatever according to their interest.

Reading comprehension is the ability to take information from written text and do something with it in a way that demonstrates knowledge or understanding of what information (Brasel 2008, p. 18). It means that comprehension 
Sihombing, The Effect of Think-Pair-Share Technique on the Students' Achievement in Reading Comprehension at the Second Semester Students of FKIP Nommensen University Pematangsiantar

is understanding the material. When the students can get comprehension from the text, they understand the message of the text. In the other words, to comprehend a text we have to able to take much information from the reading text.

The writer in teaching reading comprehension at the second semester students of FKIP Nommensen University Pematangsiantar, the writer observed that the process of comprehending a reading text was still a serious problem for the students. The writer found that the students did not understand the text so that it made them difficult to answer the questions. It can be seen when the writer still found some fault in answering the question that is related to the text. Think-Pair-Share is one of teaching alternative technique which is assumed to able to increase students' achievement in reading comprehension. ThinkPair-Share is also potentially useful to encourage students to understanding a lesson. This technique requires students to think individually about a topic or answer to a question and share ideas with pairs. Each group should answer the questions that are given by the teacher.

Based on the general background of the study above, the researcher formulates the problems as follow: "What is the effect of Think-Pair-Share technique on the students' achievement in teaching reading comprehension at the second semester students of FKIP Nommensen University Pematangsiantar?"

\section{REVIEW OF RELATED TO LITERATURE}

\section{Reading}

According to Seravallo (2010, p. 43) "reading is thinking, understanding and getting at the meaning behind a text."Reading is an extraordinary achievement when one considers the number of levels and components that must be mastered (McNamara 2006:3).Reading is a complex 
behavior which involves conscious and unconscious use of various strategies, including problem solving strategies, to build a model of the meaning, which the writer is assumed to have intended. Reading is about understanding written texts, Kamil (2003, p. 6)

From definition above, it can be said that reading is a good thing for language students. It requires student's mind as part of the process of language acquisition so that students must be able to get the meaning behind the text especially to comprehend the text.

\section{Reading Comprehension}

Brasel (2008, p. 18) stated that reading comprehension is the ability to take information from written text and do something with in a way that demonstrates knowledge or understanding of that information. Comprehension occurs when a reader is able to act on, respond to, or transform the information that is presented in written text in ways that demonstrates understanding. It illustrates how readers can show they understand what they read. Reading Comprehension is a complex task that draws on a range of skills and processes (McNamara 2006, p. 63). According to Kamil (2003, p. 6), Comprehension is the process of making sense of words, sentences and connected text.

This definition also suggests that reading comprehension requires an action on the part of the reader. That action involves the use of the existing knowledge that the reader has on the topic of the text as well as the text itself in order to create meaning. The problem in reading comprehension is making meaning from the text. The problem is solved by the intentional action of the reader, which includes the purpose for reading as well as the ability to draw upon prior knowledge that is relevant to the text. According to Brasel (2008, p. 17), Reading has different levels of comprehension: literal comprehension, inferential comprehension, critical 
Sihombing, The Effect of Think-Pair-Share Technique on the Students' Achievement in Reading Comprehension at the Second Semester Students of FKIP Nommensen University Pematangsiantar

comprehension, and creative

Think-Pair-Share

is comprehension.

\section{Think-Pair-Share Technique}

Before discussing teaching technique further, it's better to know what the 'technique' is the way a person does in order to implement a technique. According to Rostiyah (2008, p. $1)$, Technique is a knowledge of the ways of teaching used by or instructor. According to Slavin (2005, p. 56), Think-Pair-Share is a cooperative learning technique that encourages individual participation and is applicable across all grade levels and class sizes. When teachers deliver lessons to the classroom, the students sit in pairs with each team. The teacher asks the class and students are asked to think of answer of their own, then pair up with a partner to reach an agreement on an answer. Finally, the teacher asks the students to share their answers that they agree with the whole class.

4. The Procedure of ThinkPair-Share Technique 
on their ideas (pair). During the third and last stage, students responses can be shared within learning teams, with larger groups or with the entire class during a follow-up discussion (share). The job of the group should be clearly expressed.

\section{The Advantages of Think-}

Pair-Share Technique

Learning model ThinkPair-Share is best used in order to train students to think well. This emphasis on improving students, reasoning power, critical power students, the students' imagination and power of analysis to a problem (Istarani 2011 , p. 68). There is an excess of the learning model think-pairshare. They are; (1) Increase the reasoning power of students, critical power students and the analysis of student's to a problem. (2) Promote cooperation among the students as they work in groups.(3) Improve the ability of students to understand and appreciate other people's options. (5)Improve students' ability to express opinions as implementation science. (6)The teachers more likely to add knowledge of the students' when they are completed discussion.

\section{DATA ANALYSIS AND RESEARCH FINDINGS}

The result of the research consisted of the data, data analysis, the level of the students' performance, research finding and interpretation. The writer has given the test as the instrument to the students' to measure or to know the students' achievement in reading comprehension. This research is conducted in experimental group. In experimental design, the researcher is attempting to describe a casual relationship between an independent variable and a dependent variable. It means that this study intended to find out the effect of think-pairshare technique on students' achievement in reading comprehension. The writer uses quantitative research, quantitative 
Sihombing, The Effect of Think-Pair-Share Technique on the Students' Achievement in Reading Comprehension at the Second Semester Students of FKIP Nommensen University Pematangsiantar

research deals with methodology which focuses on the result. In conducting the experimental research, the sample is divided into two groups, namely the experimental group (reading comprehension by using of thinkpair-share technique) and control group (reading comprehension without using of think-pair-share technique).

\section{The Data}

The data has been collected by giving the test as instrument. The data comes from the students' score of reading test in this research. The score are obtained simply by counting the total score of the correct answer. The reading comprehension test consist of 25 items and each item will be given 4 score the answer correct, while the wrong answer is given 0 score.

\section{Data analysis of the students' score in Reading Comprehension of experimental}

The researcher has listed the marks of pre-test and posttest of experimental group in the table above. It shows that the lowest score of the pre-test is 40 and the highest is 76 , while the lowest score in post-test is 72 and the highest is 100. After listing the name and the score, the researcher calculated the sum all pre-test and post-test scores. The result showed that the sum of the pre-test $\left(\sum X\right)$ is 1952 and the sum of post-test $\left(\sum Y\right)$ is 2610. After getting the sum of pre-test and post-test then researcher squaring the score of pre-test and post-test than shown in rows of $X^{2}$ and $Y^{2}$. Then the result showed that the sum of $X^{2}$ $\left(\sum X^{2}\right)$ is 130912 and sum of $Y^{2}$ $\left(\sum Y^{2}\right)$ is 228788. While, the sum of multiplication of $\mathrm{X}$ and $\mathrm{Y}\left(\sum X Y\right)$ is 171504 . The data showed that ability of the students in post-test in more increase than in pre-test.

To find out the level of ability of the students, the writer can calculate the Mean and Standard Deviation of experimental group as follows : 


$$
\begin{aligned}
& \mathrm{n} \quad=30 \\
& \sum X i=1952
\end{aligned}
$$

a. Mean

$$
(\bar{X})=\frac{\sum X i}{n}=\frac{1952}{30}=65,06
$$

Based on the calculating above, the writer got mean of experimental group was 65,06. Then the writer calculated the mean of control group with the same formula.

b. Standard Deviation

$$
\begin{aligned}
& \mathrm{S}=\sqrt{\frac{\mathrm{N} \sum \mathrm{xi}^{2}-\left(\sum \mathrm{xi}\right)^{2}}{\mathrm{~N}(\mathrm{~N}-1)}}= \\
& \sqrt{\frac{30.130912-(1952)^{2}}{30(30-1)}} \\
& \mathrm{S}=\sqrt{\frac{117056}{870}}=11,59 \\
& \text { Based on the calculating }
\end{aligned}
$$
above, the writer got standard deviation of experimental group was 11,59 . Then the writer calculated the standard deviation of control group with the same formula.

By using the formula:

$$
\mathrm{r}_{\mathrm{xy}}=\frac{\mathrm{N} \Sigma \mathrm{XY}-(\Sigma \mathrm{X})(\Sigma \mathrm{Y})}{\sqrt{\left\{\mathrm{N} \Sigma \mathrm{X}^{2}-(\Sigma \mathrm{X})^{2}\right\}\left\{\mathrm{N} \Sigma \mathrm{Y}^{2}-\left(\Sigma \mathrm{Y}^{2}\right)\right\}}}
$$

The researcher got $r_{x y}=0,83$ while the correlation coefficient between $0,81-0,90$ is very high. So, the result showed that $r_{x y}$ is in very high value. From the result above, the researcher concluded the test of reading comprehension was give to experimental group is valid.

From the result of calculating the reliability of the test, the researcher got the score of reliability was 0,90 while $t_{\text {table }}$ and the moment product $\alpha$ $=0,05$ and $\mathrm{n}=30$, was 0,361 , so $t_{\text {obs }}>t_{\text {table }}(0,90>0,361)$. So the researcher can conclude that the test of reading comprehension for experimental group is reliable.

\section{Data analysis of the}

\section{student's score in Reading Comprehension of control group}

The researcher has listed the marks of pre-test and posttest of control group in the table above. It shows that the lowest score of the pre-test is 12 and the highest is 52 , while the lowest score in post-test is 40 and the highest is 70. After listing the name and the score, the researcher calculated the sum all pre-test and post-test scores. The result showed that the sum of the 
Sihombing, The Effect of Think-Pair-Share Technique on the Students' Achievement in Reading Comprehension at the Second Semester Students of FKIP Nommensen University Pematangsiantar

pre-test $\left(\sum X\right)$ is 890 and the sum of post-test $\left(\sum Y\right)$ is 1578. After getting the sum of pre-test and post-test then researcher squaring the score of pre-test and post-test than shown in rows of $X^{2}$ and $Y^{2}$. Then the result showed that the sum of $X^{2}\left(\sum X^{2}\right)$ is 30388 and sum of $Y^{2}\left(\sum Y^{2}\right)$ is 85428. While, the sum of multiplication of $X$ and $Y\left(\sum X Y\right)$ is 48528. The data showed that ability of the students in post-test in more increase than in pre-test.

To find out the level of ability of the students, the writer can calculate the Mean and Standard Deviation of control group as follows:

$$
\begin{aligned}
& \mathrm{n}=30 \\
& \sum X i=890
\end{aligned}
$$

a. Mean

$(\bar{X})=\frac{\sum X i}{n}=\frac{890}{30}=29,66$

Based on the calculating above, the writer got mean of control group was 29,66.

b. Standard Deviation

$$
S=\sqrt{\frac{N \sum \mathrm{xi}^{2}-\left(\sum \mathrm{xi}\right)^{2}}{\mathrm{~N}(\mathrm{~N}-1)}}=\sqrt{\frac{30.30388-(890)^{2}}{30(30-1)}}
$$

$$
S=\sqrt{\frac{119540}{870}}=\sqrt{137,40}=11,72
$$

Based on the calculating above, the writer got standard deviation was 11,72 .

By using the formula:

$$
\mathrm{r}_{\mathrm{Xy}}=\frac{\mathrm{N} \sum \mathrm{XY}-\left(\sum \mathrm{X}\right)\left(\sum \mathrm{Y}\right)}{\sqrt{\left\{\mathrm{N} \sum \mathrm{X}^{2}-\left(\sum \mathrm{X}\right)^{2}\right\}\left\{\mathrm{N} \Sigma \mathrm{Y}^{2}-\left(\sum \mathrm{Y}^{2}\right)\right\}}}
$$

The researcher got $r_{x y}=0,55$ while the correlation coefficient between $0,41-0,60$ is fair. So, the result showed that $r_{x y}$ is in fair value. From the result above, the researcher concluded the test of reading comprehension was give to control group is valid.

From the result of calculating the reliability of the test, the researcher got the score of reliability was 0,70 while $t_{\text {table }}$ and the moment product $\alpha$ $=0,05$ and $n=30$, was 0,361 , so $t_{\text {obs }}>t_{\text {table }}(0,70>0,361)$. So the researcher can conclude that the test of reading comprehension for control group is reliable.

\section{Analyzing the Data by using T- test Formula}

In order to know whether there is any effect of pre- 
questioning on students' reading comprehension achievement, the difference of mean scores on experimental group and control group are calculated by using $T$ test. The formula is:

$$
\begin{aligned}
& \mathrm{t}=\frac{\mathrm{Mx}-\mathrm{My}}{\sqrt{\left(\frac{\mathrm{dx}^{2}+\mathrm{dy}^{2}}{(\mathrm{Nx}+\mathrm{Ny})-2}\right)\left(\frac{1}{\mathrm{Nx}}+\frac{1}{\mathrm{Ny}}\right)}}= \\
& \frac{87,00-52,60}{\sqrt{\left(\frac{11,59^{2}+11,72^{2}}{(30+30)-2}\right)\left(\frac{1}{30}+\frac{1}{30}\right)}} \\
& =\frac{34,4}{\sqrt{\left(\frac{134,32+137,35}{58}\right)\left(\frac{2}{30}\right)}}=\frac{34,4}{\sqrt{(4,68)(0,06)}} \\
& =\frac{34,4}{0,52}=66,15
\end{aligned}
$$

From the calculation above, it was obtained that critical value of $t_{o b s}$ was 6 in the degree of freedom $58(\mathrm{Nx}+\mathrm{Ny}-2)$. The researcher has got the $t_{o b s}$ in df 58 at $\alpha=0,05$ was 1,67 . Based on the calculating above, the result shows that $t_{o b s}$ was higher than $t_{\text {table }}$, it could be seen as follows : $t_{o b s}>t_{\text {table }}$ or $66,15>$ 1,67

Based on the result, $t_{o b s}$ was higher than $t_{\text {table. So, the }}$ researcher concludes that there is a significant effect of ThinkPair-Share Technique on the students' achievement in reading comprehension.

\section{Research Findings}

During the researcher investigation in classroom, the ability of the students in learning English can be achieved and acknowledgement the students, because by using the technique all the students in the classroom be active in learning English, different with the class without the strategy there is just little bit students who active in learning English. In other words, studying English by using the technique is good for the students.

This research is to know the problem about the effect of teaching reading technique by Think-Pair-Share. From the analysis of data, the researcher found the score of the students, the achievement, mean, standard deviation, the validity and the reliability of the test given to the students. The validity and reliability of the test is very high, the result of the test shows that teaching English by Think-PairShare Technique at grade eight is effective because this technique 
Sihombing, The Effect of Think-Pair-Share Technique on the Students' Achievement in Reading Comprehension at the Second Semester Students of FKIP Nommensen University Pematangsiantar

can improve the students ability in English.

Having finished analyzing the data, some findings can be formulated as follows in the below that can be answered the research problems, it is the researcher finds that, there is the effect of using Think-Pair-share Technique on the students' achievement in reading comprehension, we can see experimental group gets: The highest score in pre-test is 70 and the lowest is 40 , and post-test gets the highest score is 100 and the lowest is 72 . The total scores for pre-test is 1952 and the total scores for post-test is 2610 , and the last the scores of mean in pre-test is 65,06 and the scores of mean post-test is 87,00 .

\section{CONCLUSIONS AND SUGGESTIONS}

This research is the report of finding of the data analysis, when the analysis had been described in part before. In order to know that the researcher had done his research "the effect of Think-Pair-Share technique on the students' achievement in reading comprehension at the second semester students of FKIP Nommensen University Pematangsiantar", he made out the conclusion and the suggestion as follows:

\section{Conclusions}

After doing a research and collecting the data from the second semester students of FKIP Nommensen University Pematangsiantar in order to know the effect of Think-Pair-Share Technique on the students' achievement in reading comprehension, finally the writer concludes this study as follow:

1. The students felt more enjoyable and interested in learning reading comprehension by using Think-Pair-Share Technique. It is showed by their enthusiasm while the writer applies this technique for them.

2. Think-Pair-Share Technique is suitable to apply in teaching 
reading because it can improve the students achievement in reading comprehension.

3. Teaching reading comprehension by using Think-Pair-Share Technique is significantly effects than by using Conventional Technique. It is proven based on the mean of experimental group is higher than the mean of control group $(65,06>29,66)$ and $T_{o b s}$ was higher than $T_{\text {table }}(66,15>$ $1,67)$.

\section{Suggestions}

In relation to the conclusion, some points are suggested as follows:

1. English teacher can apply Think-Pair-Share Technique in teaching reading especially in reading comprehension. Because by applying this technique, the students can improve their achievement in reading comprehension and beside that, this technique also gives the students more opportunities to interact with others in understanding the text, increase their selfconfidence and their motivation in learning English.

2. Further researchers on teaching reading especially in reading comprehension can improve their knowledge and their understanding about Think-Pair-Share Technique.

\section{REFERENCES}

Arikunto, S. (2010): Prosedur penelitian suatu pendekatan praktik-edisi revisi. Jakarta: Rineka Cipta.

Brasel, D. (2008).Comprehension That Work. Huntington Beach:Shell Education

Brown, D.H. (2001). Teaching by Principle: An Integrative Approach to Language Pedagogy. New Jersey: Prentice Hall. Burn.

Gillies, R. (2003). Cooperative Learning: The Sosial and Intellectual Outcomes of Learning in Groups.New York.

Istarani. (2011), 58 Model pembelajaran inovativ. Medan: Media Persada. 
Sihombing, The Effect of Think-Pair-Share Technique on the Students' Achievement in Reading Comprehension at the Second Semester Students of FKIP Nommensen University Pematangsiantar

Kagan, S. (2009), Cooperative Learning. San Juan Capistrano, CA: Resources for Teachers, inc.

Kamil, et al. (2003). Teaching reading. Chicago: Shell Education.
McNamara, D. (2006). Reading comprehension strategies. Lawrence Erlbaum Associates, New York.

Slavin, R. (2005). Cooperative learning. New York. Roultedge.

Serevallo, J. (2010). Teaching reading in small group. United States of America: Heneimann. 